\title{
Development of the Murine Periodontium. I. Role of Basement Membrane in Formation of a Mineralized Tissue on the Developing Root Dentin Surface
}

\author{
R. Lamont MacNeil* and Huw F. Thomas ${ }^{\dagger}$
}

THE PRESENCE OF BASEMENT MEMBRANE components on the forming root surface suggests a role for this structure during cementoblast differentiation. The purpose of this study was to investigate the role of root-associated basement membrane (RBM) in murine cementogenesis using tissue separation and recombination techniques. Root dentin specimens, with or without RBM, were combined with dental sac tissue, cultured for 2 weeks, harvested, and examined by light, immunofluorescence, and electron microscopy. Recombinations in which RBM was preserved on the root dentin surface were characterized by formation of an adherent mineralized tissue resembling acellular cementum; recombinations in which RBM was excluded were characterized by formation of mineralized tissue which did not adhere to the root dentin surface. These results suggest that formation of an adherent mineralized tissue on the developing root dentin surface is dependent upon the presence of indigenous basement membrane components. J Periodontol 1993; 64:95-102.

Key Words: Basement membrane; cementum; dentin; tooth root.

Tooth development results from a series of reciprocal, interdependent interactions between oral ectoderm and cranial neural-crest derived ectomesenchyme. ${ }^{1-5}$ While the tissue interactions leading to differentiation of ameloblasts and odontoblasts in the tooth crown have been extensively investigated, those underlying root development have only recently received attention. 6,7

Root formation begins when enamel and dentin formation in the crown has reached the cervical loop, a region where cells of the inner and outer enamel epithelia are contiguous. ${ }^{8}$ Cells of the cervical loop proliferate to form the epithelial root sheath (ERS) that grows apically, outlining the shape of the future root. ${ }^{8,9}$ Although studies have shown that root odontoblast differentiation results from an interaction between ERS and dental papilla cells, ${ }^{7}$ the tissue interactions operating during cementogenesis are unknown. Previous light and electron microscope studies of cementogenesis have shown that ERS fenestrates allowing cells of the dental sac to contact the forming root surface. ${ }^{10-16}$ Although cells of the dental sac are thought to differentiate

\footnotetext{
*Department of Periodontics/Prevention and Geriatrics, School of Dentistry, University of Michigan, Ann Arbor, MI.

†Department of Pediatric Dentistry, School of Dental Medicine, University of Connecticut Health Center, Farmington, CT.
}

into cementoblasts, ${ }^{17}$ a notion supported by autoradiograph studies, ${ }^{18}$ the mechanisms responsible for their differentiation remain unclear. Some investigations have proposed that differentiation of cementoblasts results following contact of dental sac cells with the root surface, ${ }^{17}$ while others have suggested a role for the ERS ${ }^{19}$ or its products ${ }^{20-23}$ in this process.

Examination of the forming root surface has shown that the most peripheral aspect of root dentin remains unmineralized until cementogenesis is initiated. $6,10,12,14,23,24$ Histochemical ${ }^{24}$ and ultrastructural ${ }^{6}$ studies have shown that a basement membrane is present in this location.

Basement membrane components have been shown to be biologically active and important in cell movement, differentiation, and maturation. ${ }^{25-29}$ For example, the presence of a basement membrane is required for odontoblast differentiation $^{5}$ and time-specific alterations in basement membrane composition have been mapped during tooth crown development. ${ }^{30,31}$ Additionally, the ability of basement membrane to substitute for epithelia in epithelio-mesenchymal interactions leading to osteogenesis has been established. ${ }^{32}$

The role of basement membrane in cementoblast differentiation has not yet been examined. Thus, the purpose of 
the present investigation was to determine the role of basement membrane in early root development using tissue separation and recombination techniques.

\section{MATERLALS AND METHODS}

The protocol for this study was reviewed and approved by The University of Connecticut Health Center Animal Experimentation Committee.

\section{Isolation and Preparation of Tissues}

Root dentin fragments (approximately $1.0 \times 1.5 \mathrm{~mm}$.) were obtained from mandibular first molar tooth germs from day8 postnatal CD-1 mice. ${ }^{\ddagger}$ At this stage of development, cementum had not yet formed ${ }^{33}$ and enough root structure existed for manipulation. Dentin specimens were processed in one of two ways. Some specimens were incubated in $1.0 \%$ trypsin ${ }^{\S}(1: 250)$ for 30 minutes at $4^{\circ} \mathrm{C}$ to remove both cells and basement membrane ${ }^{34}$ (i.e., D-BM); others were incubated in $0.1 \mathrm{M}$ EDTA (ethylenediaminetetraacetic acid) in $\mathrm{Ca}^{++} \mathrm{Mg}^{++}$-free HBSS (Hank's balanced salt solution) ${ }^{\S}$ for 15 minutes at $37^{\circ} \mathrm{C}$ to remove cells and to preserve the associated basement membrane ${ }^{34}$ (i.e., D + BM). Absence or presence of basement membrane components was confirmed by immunohistochemistry (see below). Absence of viable cells was ensured by freeze-thawing all specimens in distilled water $(\times 3)$ and confirmed by test culturing random specimens on $0.4 \%$ agar-supplemented minimum essential medium (MEM). $\$$

Dental sac (DS) was obtained from day-6 postnatal CD1 mice. Mandibular first molar tooth germs were removed and placed in $1.0 \%$ trypsin for 2 hours at $4.0^{\circ} \mathrm{C} .{ }^{34}$ This procedure facilitated isolation of dental sac tissue immediately subjacent to the dental papilla. ${ }^{7}$

\section{Tissue Recombination and Grafting}

The experimental groups consisted of recombinations of 1) dental sac and dentin devoid of basement membrane, group 1 (D-RBM + DS); and 2) dental sac and dentin with its preserved basement membrane, group $2(\mathrm{D}+\mathrm{RBM}+\mathrm{DS})$. Isolated tissues were recombined to duplicate their in vivo spatial orientation by using the convex surface of the dentin as reference for the peripheral, cemental-side of the root. Tissues were recombined on $0.4 \%$ agar-supplemented $\alpha$ MEM with $10 \%$ fetal bovine serum (FBS), $1.0 \%$ glutamine, and $0.1 \%$ gentamycin. Recombinations were incubated overnight in a humidified chamber with $5 \% \mathrm{CO}_{2}$ in air at $37^{\circ} \mathrm{C}$ to allow the tissues to adhere. The next day, recombinations were grafted into the anterior chamber of the eye of homologous adult male mice following established protocols. ${ }^{35}$ Animals were anesthesized with a combination of ketamine hydrochloride, $100 \mathrm{mg} / \mathrm{ml}^{l} 100 \mathrm{mg} / \mathrm{kg}$ body weight

‡Charles River Labs, Cambridge, MA.

$\S$ Sigma Chemical Co, St. Louis MO.

$\|$ Ketaset, Alveo Co., Fort Dodge, IA. and xylazine, $100 \mathrm{mg} / \mathrm{ml}^{\star} 11 \mathrm{mg} / \mathrm{kg}$ body weight. Care was taken to avoid excessive trauma during the grafting procedure; any grafting procedure that produced bleeding was excluded. One graft was placed per animal.

A total of 32 group 1 (D-RMB + DS) and group 2 $(\mathrm{D}+\mathrm{RBM}+\mathrm{DS})$ recombinations (16 each) were grafted. Control grafts $(n=5)$ consisted of dental sac tissue alone. Grafts were harvested after 2 weeks. Animals were sacrificed by cervical dislocation, the eye removed and processed for either light, immunofluorescence, or electron microscopy.

\section{Light Microscopy}

Specimens were fixed in $10 \%$ neutral buffered formalin, demineralized in formic acid/citric acid, dehydrated, cleared in xylene, and embedded in paraffin. Serial $7 \mu \mathrm{m}$ sections were cut, stained with hematoxylin and Biebrich scarlet, and examined by light microscope ( $\mathrm{n}=12$ /group).

\section{Immunohistochemistry}

Root dentin fragments and ocular graft specimens were fixed in $95 \% \mathrm{ETOH}$ and embedded in paraffin according to established protocols. ${ }^{36}$ Sections $7 \mu \mathrm{m}$ in thickness were cut, demineralized in 0.5M EDTA (pH 7.4) for 30 minutes, deparaffinized, and rinsed thoroughly in phosphate buffered saline (PBS; 0.02 M, pH 7.3). Sections were rinsed in PBS containing $1 \%$ bovine serum albumin, incubated with antibodies to keratin, laminin, or alkaline phosphatase as appropriate for 30 minutes at $37^{\circ} \mathrm{C}$ and washed for 30 minutes in PBS at room temperature. Sections were incubated with fluorescein (FITC)-labeled IgG as appropriate for $30 \mathrm{~min}$ utes at $37^{\circ} \mathrm{C}$. Finally, sections were washed for 30 minutes with PBS and coverslipped in glycerol-PBS (1:9) containing $0.1 \%$ paraphenylenediamine to reduce photobleaching $;{ }^{37}$ sections were examined in a Nikon photomicroscope equipped with epifluorescence.

Antisera were used at the following dilutions in PBS: rabbit anti-laminin (a gift from Dr. M. Tanzer, University of Connecticut) at $1 / 50$, rabbit anti-keratin ${ }^{*}$ at $1 / 100$, and rabbit anti-alkaline phosphatase (a gift from Dr. R. Majeska, Mt. Sinai School of Medicine) at 1/100. FITC-labeled second goat anti-rabbit antibody** was diluted in PBS at $1 / 100$. In controls, the first antisera were replaced with normal rabbit serum.

\section{Transmission Electron Microscopy}

Specimens from both experimental groups were fixed in $2.0 \%$ glutaraldehyde in $0.1 \mathrm{M}$ sodium cacodylate buffer (pH:7.2), post-fixed in $2.0 \%$ osmium tetroxide, dehydrated in a graded ethanol series, and embedded in Epon. Thin sections (60 to $80 \mathrm{~nm}$ ) were cut, mounted on formvarcoated grids, stained with uranyl acetate and lead citrate,

IRompun, Mobay Corp., Shawnee, KS.

\#Dako Corp., Santa Barbara, CA.

**Miles Scientific, Naperville, IL. 
Table 1. Summary of Tissue Recombinations Involving Dentin (D), Root Basement Membrane (RBM), and Dental Sac (DS)

\begin{tabular}{|c|c|c|c|c|c|c|}
\hline \multirow[b]{2}{*}{ Group } & \multirow{2}{*}{$\begin{array}{c}\text { Tissues } \\
\text { Used }\end{array}$} & \multirow[b]{2}{*}{$\mathrm{n}$} & \multicolumn{2}{|c|}{ Immunofluorescence } & \multicolumn{2}{|c|}{ Mineralization } \\
\hline & & & Keratin & AP & Non-Adherent & Adherent \\
\hline \multirow{5}{*}{$\begin{array}{l}\text { Control } \\
1\end{array}$} & DS & 5 & - & + & $\mathrm{n} / \mathrm{a}$ & $\mathrm{n} / \mathrm{a}$ \\
\hline & DS, & & & & $10 / 12$ & $2 / 12$ \\
\hline & D-RBM & 16 & - & + & $(83 \%)$ & $(17 \%)$ \\
\hline & DS, & & & & $0 / 12$ & $12 / 12$ \\
\hline & $\mathrm{D}, \mathrm{RBM}$ & 16 & - & + & $(0 \%)$ & $(100 \%)$ \\
\hline
\end{tabular}

and examined on a Philips 410LS or JEOL 100CX electron microscope $(\mathrm{n}=2 /$ group $)$.

\section{RESULTS}

\section{Root Dentin Specimens}

Examination of specimens reacted with antiserum to laminin confirmed the successful removal (D-RBM) or preservation $(\mathrm{D}+\mathrm{RBM})$ of basement membrane components on the root dentin surfaces. Trypsin-treated dentin revealed no specific staining for laminin (Fig. 1.A) while EDTA-treated dentin demonstrated staining along the outer (cemental) surface of the root (Fig. 1.B). In the random samples that were test cultured, no evidence of cellular outgrowth was observed, confirming successful removal of cells from the root surface.

\section{Tissue Recombinations}

Our findings are summarized in Table 1. All 5 control grafts (DS alone) formed a mineralized tissue that resembled early woven bone or cellular cementum (Fig. 2.A). This mineralized tissue contained cell with basophilic interspersed within an acidophilic osteoid-like matrix. Cells within and surrounding this bone-like tissue demonstrated positive staining for alkaline phosphatase (Fig. 2.B).

Mineralized tissue formed in all recombinations of dental $\mathrm{sac}$ and root dentin. A consistent finding was formation of an adherent mineralized tissue on the predentin (pulpal) aspect of the root dentin specimens (Fig. 3). Although mineralized tissue also formed on the peripheral (cemental) aspect of the root piece, a clearly defined space was found between this tissue and the dentin surface in most group 1 (D-RBM + DS) specimens; i.e., 10 out of 12 specimens $(83 \%)$. Space formation consistently occurred at the peripheral dentin surface but was never noted within the dentin or mineralized matrix (Fig. 3). In contrast, in all group 2 recombinations (D $+\mathrm{RBM}+\mathrm{DS})$; i.e., 12 out of $12 \mathrm{spec}$ imens $(100 \%)$, mineralized tissue formed and adhered to the dentin surface (Fig. 4). A well-defined hematoxylin line demarcated the interface of the dentin surface and adhering mineral; artifactual tearing or separation of the mineralized tissue away from the dentin surface was not observed. In contrast to the mottled, cellular appearance of the mineralized tissue seen in more peripheral sites, the zone of newly formed mineralized tissue immediately adjacent to dentin appeared uniformly acellular.

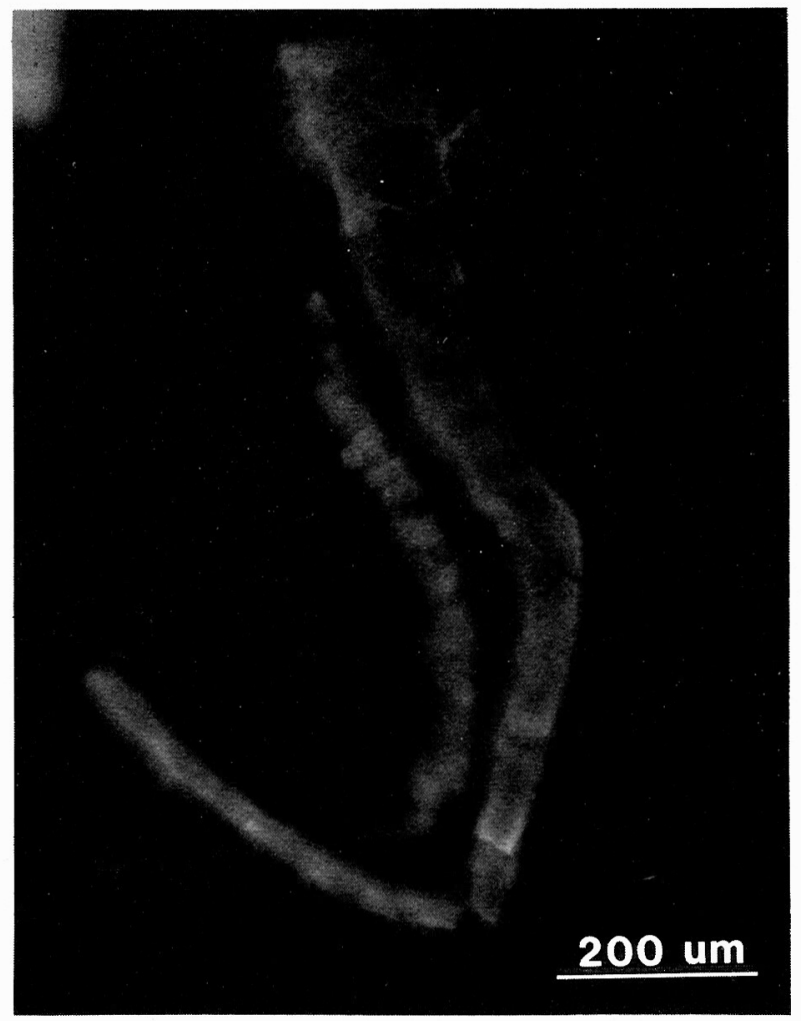

Figure 1.A. Trypsin-treated dentin specimen after incubation with antiserum to laminin. No evidence of staining for laminin is present (bar = $200 \mu \mathrm{m})$.

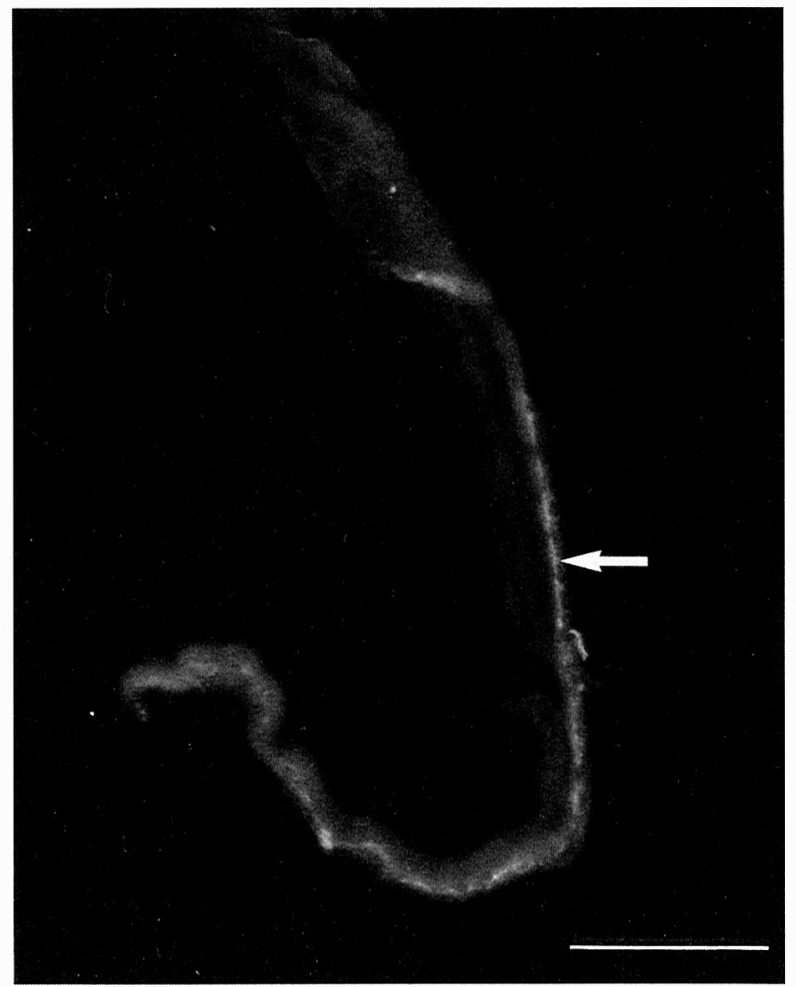

Figure 1.B. EDTA-treated dentin specimen incubated with antiserum to laminin. Positive staining for laminin (arrow) is evident on the peripheral (cemental) surface of the root dentin specimen (bar $=200 \mu \mathrm{m})$. 


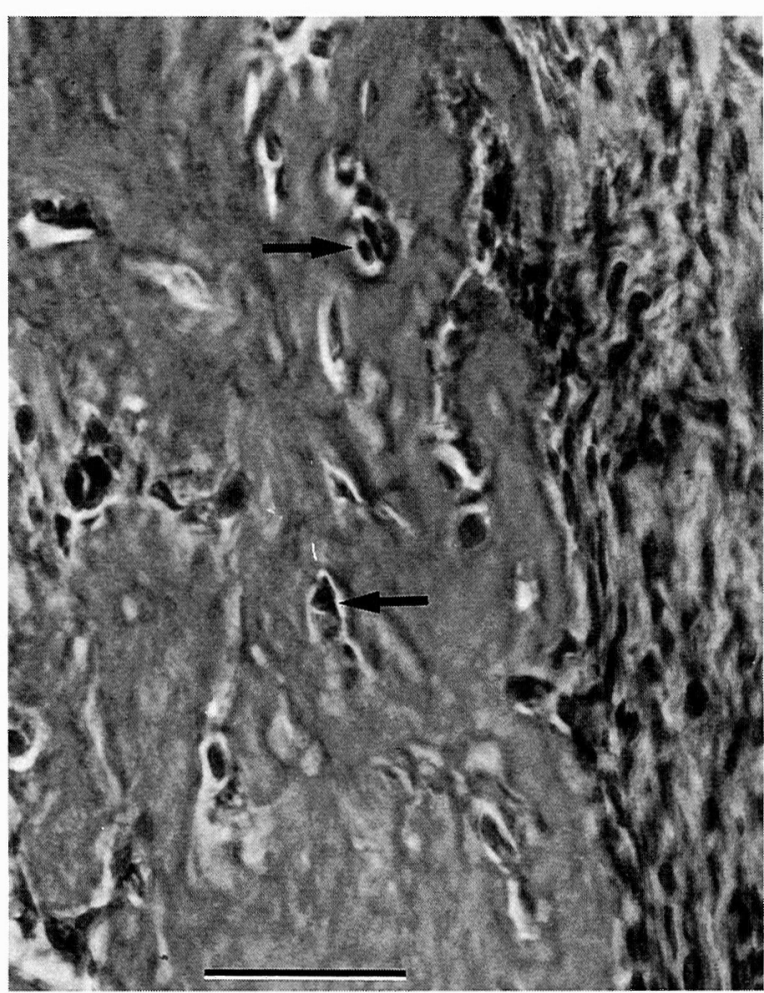

Figure 2.A. Control group (dental sac) demonstrating formation of a bonelike tissue. Cells (arrows) are entrapped within the mineralized matrix $($ bar $=100 \mu \mathrm{m})$.

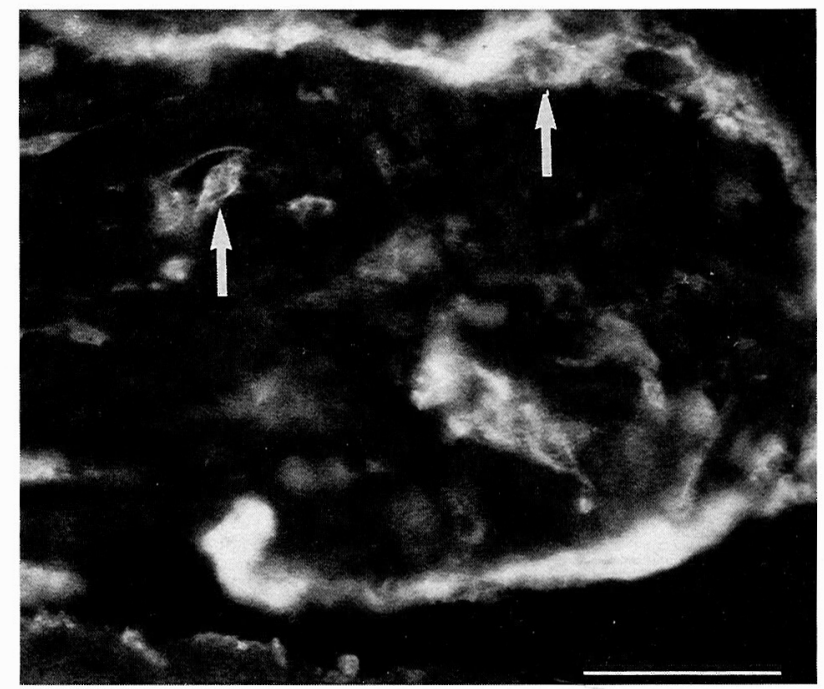

Figure 2.B. Control group specimen after incubation with antiserum to alkaline phosphatase. Cells within and surrounding the mineralized tissue display positive staining for alkaline phosphatase (arrows) (bar $=100 \mu \mathrm{m})$.

\section{Immunohistochemistry}

Specimens from all groups lacked specific staining for cytokeratins (Fig. 5.A) confirming that the isolation procedures used were successful in removing all epithelial components (including ERS) from dental sac tissue. Specimens from both groups demonstrated positive staining for alkaline phosphatase similar to that found in control grafts.

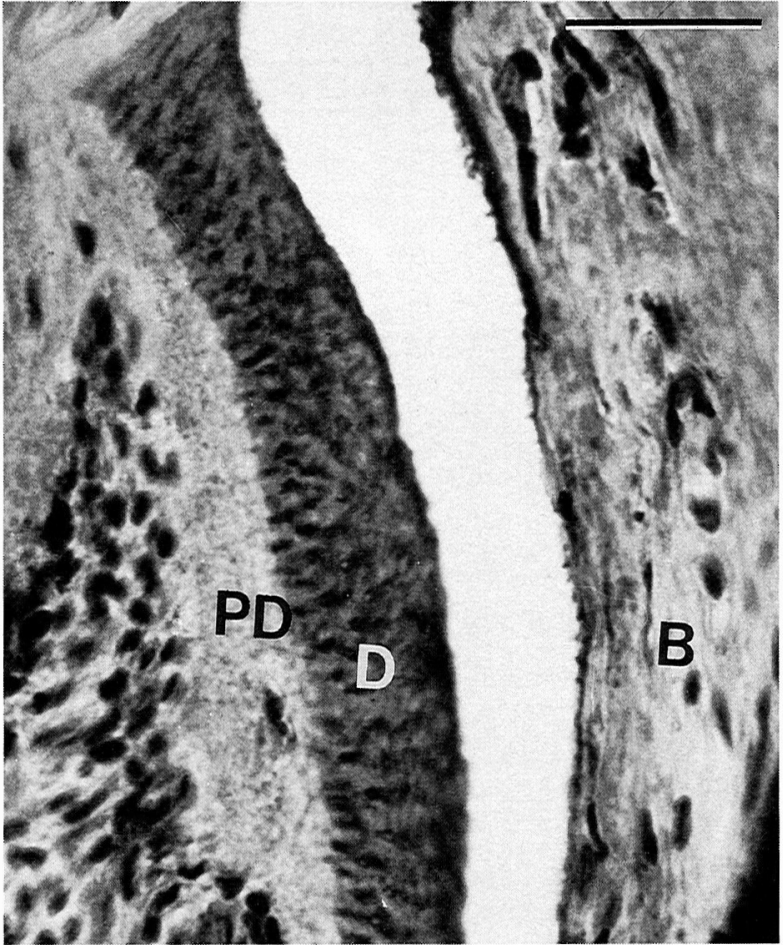

Figure 3. Light micrograph of a group 1 recombination. A space is present between the peripheral dentin surface $(D)$ and the overlying mineralized material $(B)$. Bone has fused to the predentin $(P D)$ surface $($ bar $=100 \mu \mathrm{m})$.

Staining was localized to cells within the matrix and those lining the mineralized tissue (Fig. 5.B).

\section{Transmission Electron Microscopy}

Ultrathin sections of group 1 specimens revealed an incomplete union of mineral to root dentin (Fig. 6). The interface between newly formed mineral and dentin was characterized by a zone of tearing or separation which occurred to varying degrees. Inspection of the tear area revealed separation of mineral from dentin at its peripheral surface, similar to that observed by light microscopy (Fig. 6).

In contrast to group 1 specimens, separation of mineral from the dentin surface was not observed in group 2 specimens. In group 2 recombinations, the native dentin surface was covered by an adherent collagenous extracellular matrix exhibiting focal areas of mineralization (Fig. 7). Mineralization was most advanced at the dentin surface and radiated as a mineralization front toward more peripherally placed cells and matrix. Flattened cells resembling cementoblasts lined the mineralization front in an ordered, parallel fashion (Fig. 8); these cells were separated from the underlying mineralized substratum by a zone of densely packed, irregularly-arranged collagen fibers (Fig. 8). Dentinal resorption was not observed on the root surface.

\section{DISCUSSION}

The experimental techniques of tissue separation and recombination have been instrumental in delineating the role 


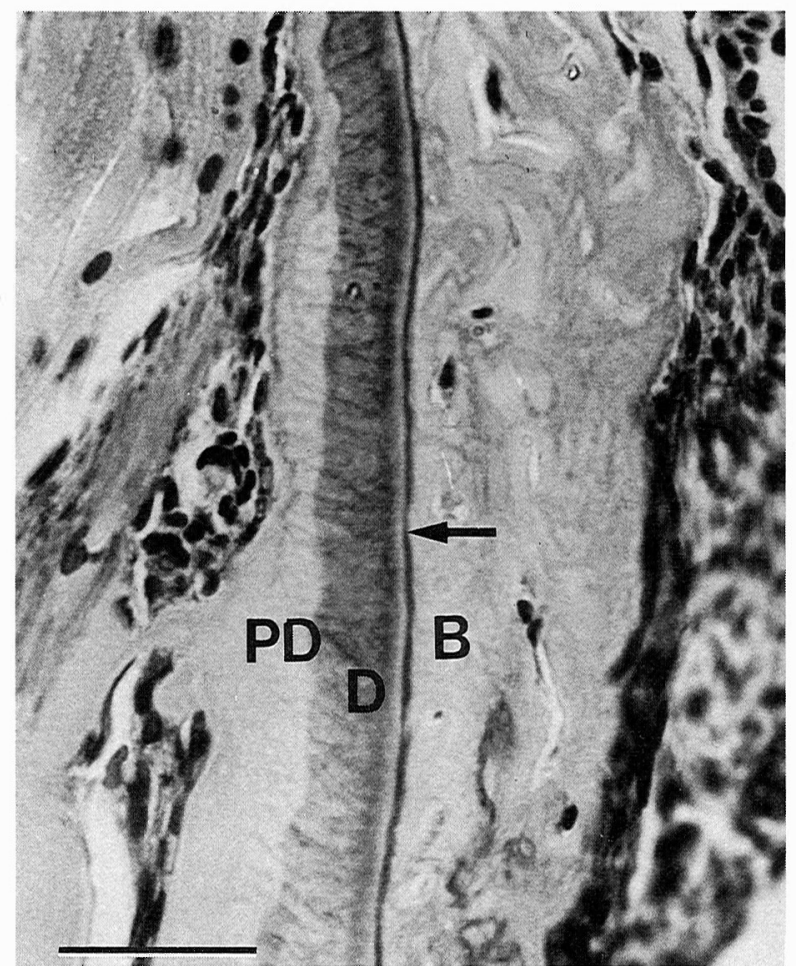

Figure 4. Light micrographs of a group 2 recombination. A predominantly acellular, bone-like material $(B)$ has been deposited on the dentin specimen (D). A darkly-staining hematoxylin line delineates the junction of the bone and dentin. An acellular mineralized tissue has also formed on the predentin $(P D)$ surface (bar $=100 \mu \mathrm{m})$.

of specific tissues in early tooth development. ${ }^{7,38,43}$ These techniques have been adapted in this present study to investigate the tissue interactions operative during root development and cementogenesis. Our results confirm the ability of dental sac to form a mineralized tissue, as demonstrated by others. ${ }^{35,43}$ Further, we provide evidence that formation of a dental sac-derived mineralized tissue on dentin is dependent upon the presence of basement membrane components indigenous to the developing root surface.

The 3 tissues which comprise the periodontal attachment - cementum, periodontal ligament, and alveolar bone are thought to originate from embryonic dental sac or follicle. ${ }^{18,35}$ However, the precise role which dental sac plays in the differentiation and maturation of these tissues is unknown due largely to technical inability to rule out contributions from other closely-approximated embryonic tissues; e.g., dental papilla and perifollicular mesenchyme. The ability to isolate individual tooth germ components in this study allowed the controlled investigation of the role of dental sac and other designated tissues in periodontal attachment formation. Overall, the results of this investigation demonstrate that dental sac can form mineralized tissue either alone (control group) or in combination with dentin (groups 1 and 2).

The formation of an adherent mineralized tissue on the predentin (pulpal) aspect of the root dentin specimens was

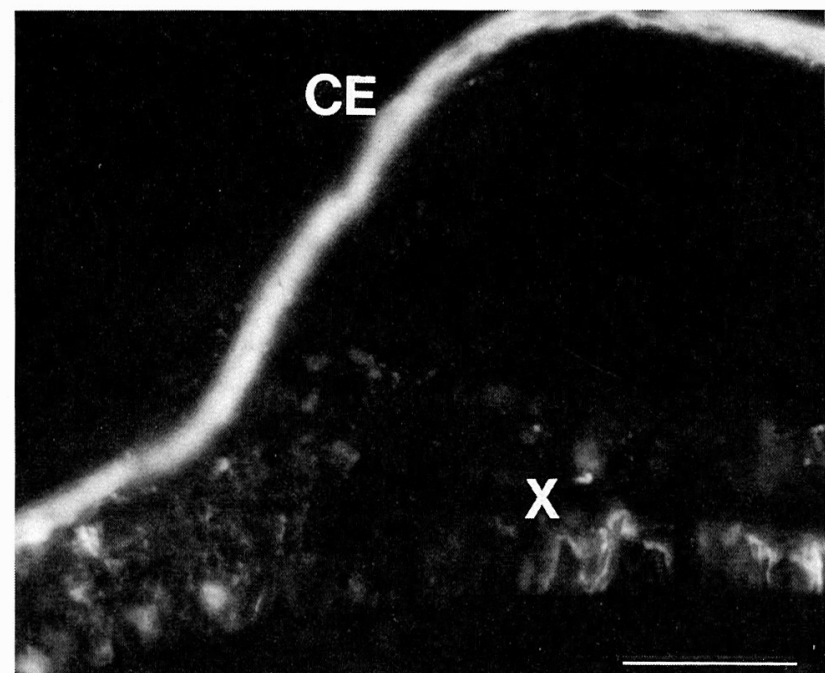

Figure 5.A. Group 1 specimen incubated with antiserum to keratin. Cells of the corneal epithelium (CE) serve as a positive control. Transplanted tissues $(X)$ within the anterior eye chamber lack specific staining for keratin confirming exclusion of odontogenic epithelium (bar $=200 \mu \mathrm{m}$ ).

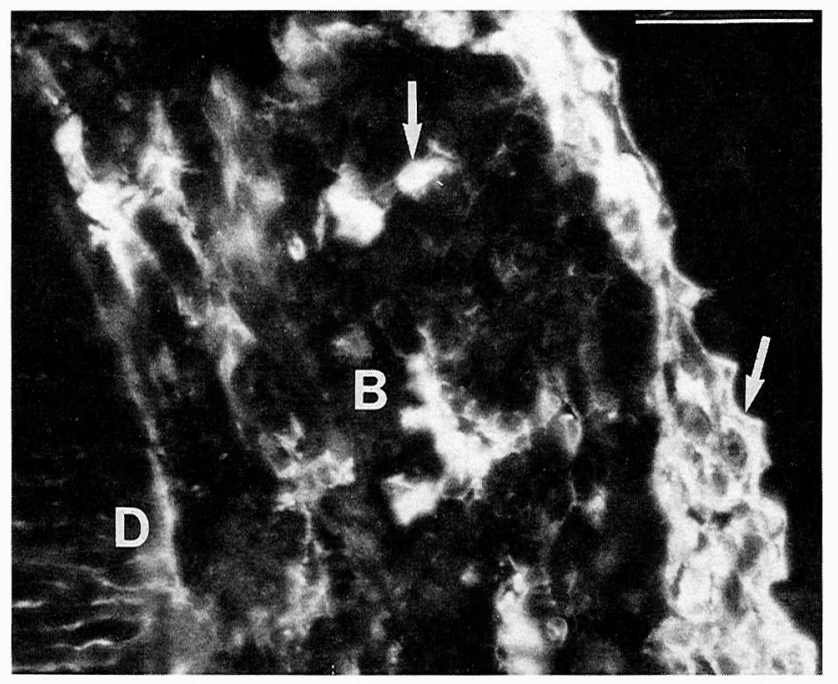

Figure 5.B. Group 2 specimen incubated with antiserum to alkaline phosphatase (AP). A bone-like material $(B)$ is fused to the dentin $(D)$ specimen on the lower left. Cells within and surrounding this adherent mineralized material display positive staining for $A P$ (arrows) (bar $=100 \mu \mathrm{m}$ ).

anticipated. Previous investigations $s^{6,7}$ have demonstrated that the unmineralized predentin matrix supports mineralization activity in various tissues including dental papilla and dental sac; the osteoinductive nature of demineralized dentin is believed to be related to the presence and exposure of collagenous ${ }^{44}$ and noncollagenous proteins within the dentin matrix. ${ }^{45}$

While mineralized tissue also formed on the outer (periodontal) aspect of the dentin fragments, groups 1 and 2 differed markedly in the type of tissue response observed at the dentin-mineral interface. In group 2 recombinations, where basement membrane components were preserved, an adherent, acellular, mineralized tissue formed on the dentin surface. In contrast, when the intervening basement mem- 


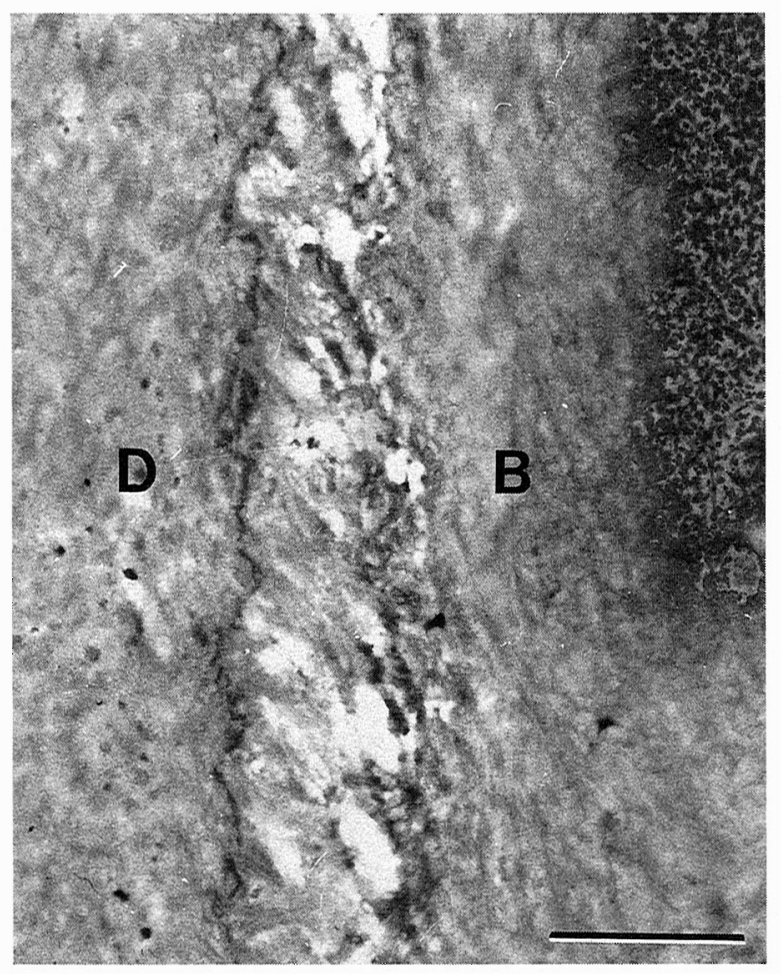

Figure 6. Transmission electron micrograph (TEM) of a group 1 specimen demonstrating space formation between bone $(B)$ and dentin $(D)($ bar $=$ $2 \mu \mathrm{m})$.

brane was absent (group 1), mineralized tissue formed peripheral to the dentin surface and adherence to dentin failed

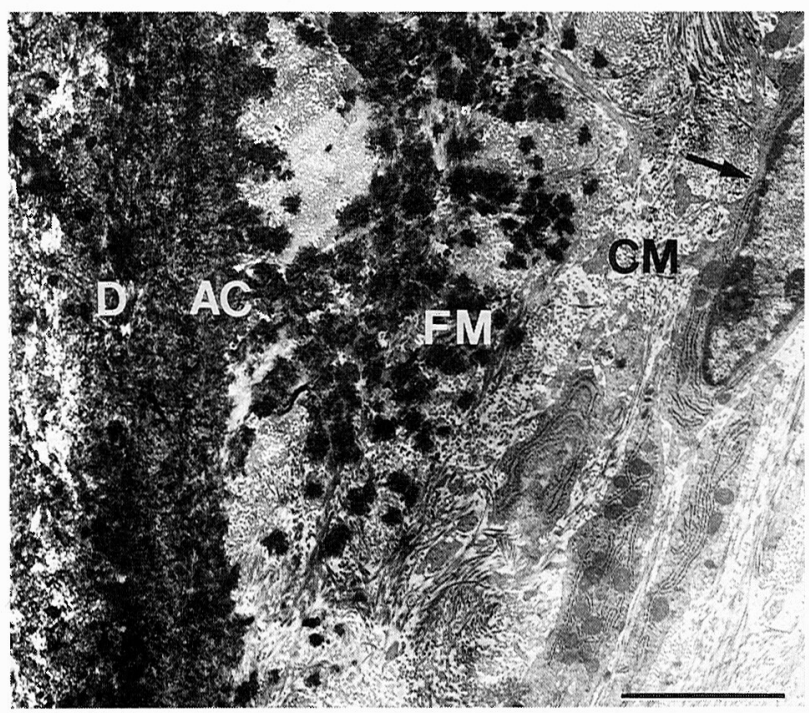

Figure 7. TEM of a group 2 specimen. An acellular material $(A C)$ has been deposited on the dentin surface $(D)$. Foci of mineralization (FM) radiate outward into a dense, irregularly-arranged collagenous matrix (CM) containing mesenchymal-like cells (arrow) (bar $=4 \mu \mathrm{m})$.

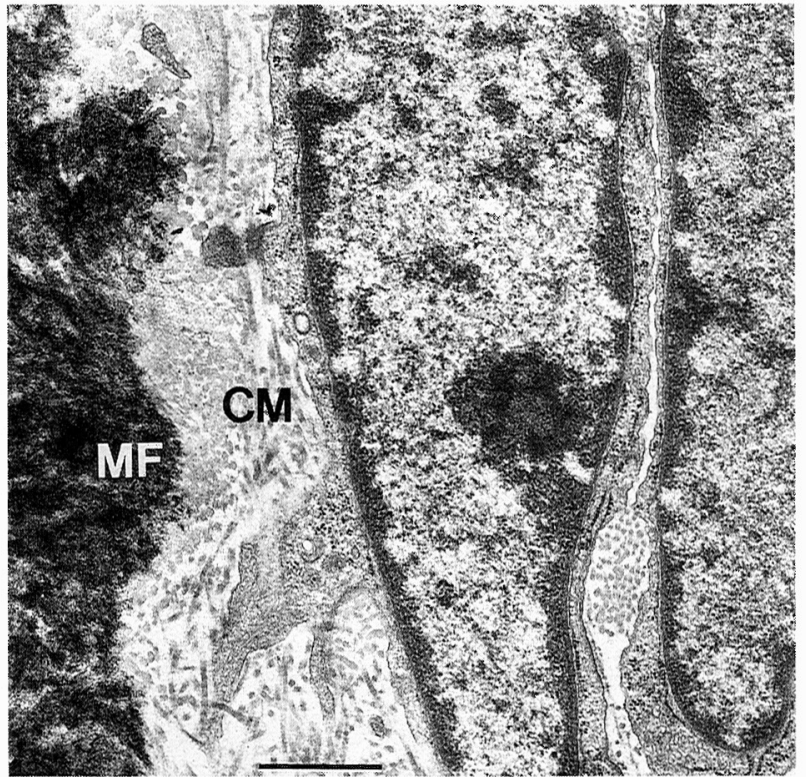

Figure 8. Higher magnification of the mineral-cell interface. A collagenous matrix (CM) separates a large lining cell from the mineralization front $(M F)$. Collagen fibrils at the mineral surface appear in cross section while those closer to the cell are oriented parallel to the mineralization front $($ bar $=1 \mu \mathrm{m})$.

to occur in $83 \%(10 / 12)$ of the recombinations. We feel that the formation of a dentin-mineral attachment in a small number of group 1 recombinations is most likely attributable to incomplete removal of basement membrane components in these isolated cases.

It is interesting to speculate as to the nature of the mineralized tissue which formed on dentin in group 2 recombinations. Previous investigations have correlated the formation of the first-formed (acellular) cementum with the appearance of a hematoxylin-staining line on the root dentin surface, ${ }^{24}$ a similar cemental line is found in group 2 specimens between the adhering mineral and the native dentin surface. Ultrastructural analysis of this interface in group 2 recombinations revealed a narrow zone of densely mineralized tissue bordered peripherally by a mineralized front. Cells lining the mineralization front resembled osteoblasts or cementoblasts: lining cells exhibited large nuclei, abundant rough endoplasmic reticulum and mitochondria, appeared actively engaged in collagen synthesis, and assumed a parallel orientation to the mineralization front. Thus, based on histologic criteria alone, this tissue shares many of the characteristics of early acellular cementum, ${ }^{12,13,15,24}$ however, in the absence of a known biological marker for cementum, this designation cannot be reliably made.

These results suggest that mineral formation on the forming root dentin surface is dependent upon the presence of basement membrane components. Similar observations were made 35 years ago by Paynter and Pudy ${ }^{24}$ who hypothesized 
that the retained basement membrane might serve as a substrate for the initial deposition of mineral. Since that time it has become apparent that basement membrane components, while possessing mechanical properties (e.g., adhesiveness), also possess a variety of biological properties including modulation of cell attachment, proliferation, movement, and differentiation. ${ }^{25,27-29}$ During tooth development, cell-cell and cell-matrix interactions are thought to occur, in part, by binding of basement membrane component molecules to integrin-type cell membrane receptors. ${ }^{46,47}$ For example, the series of epithelio-mesenchymal cell interactions which regulates the differentiation of ameloblasts and odontoblasts is intricately coupled to timespecific alterations in protein composition of the intervening basement membrane. ${ }^{30,31}$ In a similar manner, root-associated basement membrane could potentially serve a regulatory role in cementoblast differentiation. The binding of dental sac cells to specific root basement membrane components via timed expression of integrin receptors may represent a mechanism whereby cementoblast differentiation is temporally and spacially regulated. This hypothesis is currently being addressed in ongoing experiments in our laboratory.

Findings from this study may have important implications in the field of periodontal regeneration. Considerable research effort has been devoted to defining the progenitor tissue from which periodontal cells originate. ${ }^{48-52}$ Cell labeling studies ${ }^{48-50}$ and in vitro investigations ${ }^{51,52}$ have been unable thusfar to determine if this stem cell compartment resides in the periodontal ligament, alveolar bone, or other tissues. Melcher et al. have suggested that periodontal progenitor cells may originate from the endosteal spaces of alveolar bone based on the observation that calvarial cells produce mineralized tissue in vitro while PDL cells lack this ability. ${ }^{51}$ Conversely, Arceo et al. have recently reported that PDL cells, but not gingival fibroblasts, are capable of producing mineral-like nodules under similar in vitro culture conditions. ${ }^{52}$ Findings from this present study, however, suggest that cells with mineralizing potential require a specific substrate condition on root dentin before differentiation and mineralized matrix deposition can occur; the absence of these extracellular conditions in previous experiments may explain the wide variation in reported findings. Additionally, if these biologic requirements persist post-developmentally, stem cell populations may require similar extracellular matrix conditions on the mature root prior to cementoblast differentiation during conditions of periodontal regeneration and repair.

Our results suggest that murine root formation is dependent upon cell-matrix interaction(s) between dental sac cells and root-associated basement membrane components. As the basement membrane is partially of epithelial origin, this interaction may be similar to the epithelio-mesenchymal interactions which occur in earlier phases of tooth development. Thus, development of root and periodontal attach- ment may be best considered a continuation of the initiating and reciprocal interactions which occur between epithelium and mesenchyme in early tooth crown development.

\section{Acknowledgments}

This study was supported by NIH grants DE 07075 and DE 07090. The authors would like to express their appreciation to Ms. Patty Indelicato, Ms. Lavinia Muncie, and Ms. Chris Pearson for their technical assistance during this study.

\section{REFERENCES}

1. Kollar EJ. Histogenetic aspects of dermal-epidermal interactions. In: Slavkin HC, Bavetta LA, eds. Developmental Aspects of Oral Biology. New York: Academic Press; 1972; 126-149.

2. Slavkin HC. Embryonic tooth formation. A tool for developmental biology. In: Melcher AH, Zarb GA, eds. Oral Sciences Reviews. Copenhagen: Munksgaard; 1974; 1-136.

3. Thesleff $I$, Hurmerinta $K$. Tissue interactions in tooth development. Differentiation 1981; 18:75-88.

4. Kollar EJ. Epithelial-meschymal interactions in the mammalian integument. Tooth development as a model for instructive induction. In: Sawyer RH, J. Fallon J, eds. Epithelial-mesenchymal Interactions in Development. New York: Praeger Press; 1983; $27-41$.

5. Ruch JV. Tooth morphogenesis and differentiation. In: Linde A, ed. Dentin and Dentinogenesis. Boca Raton: CRC Press, 1984; 47-49.

6. Thomas HF, Kollar EJ. Tissue interactions in normal murine root development. In: Davidovitch Z, ed. The Biological Mechanisms of Tooth Eruption and Root Resorption. Birmingham, AL: EBSCO Media; 1988; 145-152.

7. Thomas HF, Kollar EJ. Differentiation of odontoblasts in grafted recombinations of murine epithelial root sheath and dental mesenchyme. Arch Oral Biol 1989; 34:27-35.

8. Diamond M, Applebaum E. The epithelial sheath: Histogenesis and function. $J$ Dent Res 1942; 21:403-411.

9. Hertwig, $O$ Ueber das zahnsystem der amphibien und seine bedeutung fur die genese des skelets der munhole. Arch Mikr Anat 1874; 11(suppl):55-56.

10. Selvig KA. Electron microscopy of Hertwig's epithelial sheath and of early dentin and cementum formation in the mouse incisor. Acta Odontol Scand 1963;21:175-186.

11. Selvig KA. An ultrastructural study of cementum formation. Acta Odontol Scand 1964; 22:105-120.

12. Lester KS. The incorporation of epithelial cells by cementum. $J U l$ trastruct Res 1969; 27:63-87.

13. Lester KS. The unusual nature of root formation in molar teeth of the laboratory rat. J Ultrastruct Res $1969 ; 28: 481-506$.

14. Ten Cate AR. A fine structural study of coronal and root dentinogenesis in the mouse. Observations of the so-called "von Korff fibers" and their contribution to mantle dentin. J Anat 1978; 125:183197.

15. Owens PDA. Light and electron microscopic study of the early stages of root surface formation in molar teeth in the rat. Arch Oral Biol 1980; 24:901-907.

16. Rademakers LHPM, Slootweg PJ, van Blokland WTM. An ultrastructural study of cytodifferentiation in the developing human root tip. Arch Oral Biol 1985; 30:655-660.

17. Armitage GC. Cementum. In: Bashkar SN, ed. Orban's Oral Histology and Embryology, 10th ed. St. Louis: CV Mosby; 1986; 175197.

18. Ten Cate AR, Mills C, Solomon G. The development of the periodontium: A transplantation and autoradiograph study. Anat Rec 1971; 170:365-380. 
19. Schour I, Massler MM. Studies in tooth development: The growth patterns of human teeth. J Am Dent Assoc 1940; 27:1918-1931.

20. Slavkin HC. Towards a cellular and molecular understanding of periodontics. Cementogenesis revisited. J Periodontol 1976; 47:249255.

21. Lindskog S, Hammarstrom L. Formation of intermediate cementum III. 3-H-Tryptophan and 3-H proline uptake into the epithelial root shealth of Hertwig in vitro. J Craniofac Genet Dev Biol 1982; 2:11177.

22. Slavkin HC, Bringas P Jr, Bessem C, et al. Hertwig's epithelial root sheath differentiation and initial cementum and bone formation during long term culture of mouse mandibular first molars using serumless, chemically-defined medium. J Periodont Res 1989; 24:28-40.

23. Cho M-I, Garant PR. Ultrastructural evidence of directed cell migration during initial cementoblast differentiation in root formation. $J$ Periodont Res 1988; 23:268-276.

24. Paynter KJ, Pudy G. A study of the structure, chemical nature, and development of cementum in the rat. Anat Rec 1958; 131:233-251.

25. Kefalides NA, Alper R, Clark CC. Biochemistry and metabolism of basement membranes. Int Rev Cytol 1979; 61:167-228.

26. Yamada KM, Kennedy DW, Kimata K, Pratt RM. Characterization of fibronectin interactions with glycosaminoglycans and identification of active proteolytic fragments. $J$ Biol Chem 1980; 255:6055-6063.

27. Kleinman HK, Klebe RJ, Martin GR. Role of collagenous matrices in the adhesion and growth of cells. J Cell Biol 1981; 88:473-485.

28. Bernfield M. Basement membranes and cell movement. In: Porter $R$, Whelen J, eds. Ciba Foundation Symposium \#108. London: Pittman Co,; 1984; 1-6.

29. Terranova VP, Wikesjö UME. Extracellular matrices and polypeptide growth factors as mediators of functions of cells of the periodontium - a review. J Periodontol 1987; 58:371-380.

30. Lesot H, Osman M, Ruch JV. Immunofluorescent localization of collagen, fibronectin, and laminin during terminal differentiation of odontoblasts. Dev Biol 1981; 82:371-381.

31. Thesleff I, Barrach HJ, Foidart JM, Vaheri A, Pratt RM, Martin GR. Changes in the distribution of type IV collagen, laminin, proteoglycan and fibronectin during mouse tooth development. Dev Biol 1981; 81:182-192.

32. Hall BK, van Exan RJ. Induction of bone by epithelial cell products. J Embryol Exp Morphol 1982; 69:37-46.

33. Cohn SA. Development of the molar teeth in the albino mouse. $A m$ $J$ Anat 1957; 101:295-319.

34. Osman M, Ruch JV. Secretion of basal lamina by trypsin-isolated embryonic mouse molar epithelia cultured in vitro. Dev Biol 1980; 75:467-470.

35. Yoshikawa DK, Kollar EJ. Recombination experiments on the odontogenic roles of mouse dental papilla and dental sac tissues in ocular grafts. Arch Oral Biol 1981; 12:745-753.

36. Sainte Marie G. A paraffin-embedding technique for studies employing immunofluorescence. J Histochem Cytochem 1962; 10:250-255.
37. Johnson GD, Norueira Araujo, GM. A simple method to reduce fading of immunofluorescence during microscopy. J Immunol Methods 1981; 43:349-50.

38. Huggins CB. The formation of bone under the influence of the urinary tract. Arch Surg 1931; 22:377-408.

39. Kollar EJ, Baird G. The influence of the dental papilla in the development of tooth shape in embryonic mouse tooth germs. $J$ Embryol Exp Morphol 1969; 21:131-148.

40. Kollar EJ, Baird G. Tissue interactions in mouse tooth germs. I. Reorganization of the dental epithelium during tooth germ reconstruction. J Embryol Exp Morphol 1970; 24:159-171.

41. Kollar EJ, Baird G. Tissue interactions in mouse tooth germs. II. The inductive role of the dental papilla. J Embryol Exp Morphol 1970; 24:173-186.

42. Kollar EJ, Fisher C. Tooth induction in chick epithelium: Expression of quiescent genes for enamel synthesis. Science 1980; 207:993-995.

43. Palmer RM, Lumsden AG. Development of periodontal ligament and alveolar bone in homografted recombinations of enamel organs and papillary, pulpal, and follicular mesenchyme in the mouse. Arch Oral Biol 1987; 32:281-289.

44. Bang G, Johannessen JV. The effect of proteolytic enzymes on the induction of heterotypic bone formation by demineralized dentin in guinea pigs. J Oral Path 1972; 1:221-239.

45. Butler WT. Dentin specific proteins. In: Cunningham LW, ed. Enzymology: Extracellular Matrix, Part C. New York: Academic Press; 1987;145:290-303.

46. Hynes RO. Integrins: A family of cell surface receptors. Cell 1987; 48:549-554.

47. Rouslahti E. Integrins. J Clin Invest 1991; 87:1-5.

48. Ten Cate AR, Mills C. The development of the periodontium: The origin of alveolar bone. Anat Rec 1972; 173:69-78.

49. Aukhil I, Iglhaut J. Periodontal ligament cell kinetics following experimental regenerative procedures. J Clin Periodontol 1988; 15:374 382.

50. McCulloch CAG, Nemeth E, Lowenberg B, Melcher AH. Paravascular cells in endosteal spaces of alveolar bone contribute to periodontal ligament cell populations. Anat $\operatorname{Rec} 1$ 1987; 219:233-242.

51. Melcher AH, Cheong TK, Cox J, Nemeth E, Shigoi A. Synthesis of cementum-like tissue in vitro by cells cultured from bone. A light and electron microscopic study. $J$ Dent Res 1986; 21:591-6132.

52. Arceo N, Sauk JJ, Moehring J, Foster R, Somerman MJ. Human periodontal ligament cells initiate mineral-like nodules in vitro. $J$ Periodontol 1991; 62:499-503.

Send reprint requests to: Dr. R. Lamont MacNeil, Department of Periodontics/Prevention and Geriatrics, School of Dentistry, University of Michigan, Ann Arbor, MI 46109-1078.

Accepted for publication August 10, 1992. 